\title{
INFORMATION TECHNOLOGY IN EDUCATION
}

\author{
DOI https://doi.org/10.30525/978-9934-26-115-2-9
}

\section{ІНФОРМАЦЙНА СИСТЕМА ПЕРЕВІРКИ ЗНАНЬ КАНДИДАТІВ НА ПОСАДУ QА ENGINEER}

\author{
Бойко О. В. \\ кандидат технічних наук, \\ старший викладач кафедри комп'ютерних наук \\ Сумський державний університет \\ Іванченко I. М. \\ студент \\ Сумський державний університет \\ м. Суми, Украӥні
}

Починаючи з 2020 року внаслідок Covid19 відбулися стрімкі зміни на ринку праці багатьох областей. 3 одного боку, робота отримала дистанційний формат, а 3 іншого, великій кількості працівників необхідно опановувати нові спеціальності. Це спричинило більший попит на фахівців 3 програмування та QА тестувальників [1].

Ще на першому етапі працевлаштування необхідно перевіряти знанння кандидатів. Невдалий підбір кандидатів змушує роботодавців зазнавати значних збитків. Тому сьогодні є актуальним оптимізація процесу підбору кандидатів на вакантні посади шляхом проведення автоматизованого тестування знань. Це дозволить спростити i прискорити процедуру відбору серед великої кількості претендентів. 
Тому у роботі поставлено за мету розробити інформаційну систему оцінювання знань 3 тестування програмного забезпечення (ICO3T). Така система повинна представляти собою платформу як для роботодавців, так і для кандидатів. Головна ідея - перевірити та оцінити знання та навички потенційних співробітників у сфері тестування програмного забезпечення. Допуск тільки підготовлених фахівців до послідуючих співбесід допоможе пришвидшити процес знаходження висококваліфікованих кадрів, а також дозволить скоротити витрати та час для роботодавця.

На сьогоднішній день існує велика кількість інформаційних додатків чи веб-сайтів для перевірки знань кандидатів на посади за різними спеціальностями. Найбільш часто застосовані додатки та їх порівняльна характеристика представлена у таблиці 1.

Таблиця 1

Порівняльна характеристика аналогів

\begin{tabular}{|c|c|c|c|c|c|}
\hline & $\begin{array}{c}\text { Назва } \\
\text { критерію }\end{array}$ & $\begin{array}{c}\text { Interview } \\
\text { Mocha }\end{array}$ & $\begin{array}{c}\text { Google } \\
\text { Forms }\end{array}$ & CodinGame & $\begin{array}{c}\text { Assessment } \\
\text { Day }\end{array}$ \\
\hline 1 & $\begin{array}{c}\text { Присутність } \\
\text { реклами }\end{array}$ & + & - & + & + \\
\hline 2 & $\begin{array}{c}\text { Поділення на } \\
\text { категорії }\end{array}$ & + & - & + & + \\
\hline 3 & Доступність & - & + & + & - \\
\hline 4 & $\begin{array}{c}\text { Зручність } \\
\text { використання }\end{array}$ & + & + & + & + \\
\hline 5 & $\begin{array}{c}\text { Зрозумілий } \\
\text { інтерфейс }\end{array}$ & + & + & + & + \\
\hline 6 & $\begin{array}{c}\text { Онлайн } \\
\text { доступ }\end{array}$ & + & + & + & - \\
\hline 7 & $\begin{array}{c}\text { Перегляд } \\
\text { статистики }\end{array}$ & + & + & - & + \\
\hline
\end{tabular}


Нова інформаійна система повинна містити в собі переваги існуючих систем-аналогів, та долати їх недоліки. Додатковими вимогами є: відсутність реклами, поділ на категорії, доступність усім бажаючим. Претенденти матимуть можливість проходити тестування, а спеціалісти HR можуть розробляти тести з використанням вбудованого конструктора, розміщати публікації на сторінках, збирати статистичну інформацію, складати рейтинги оцінок кандидатів за результатами перевірочних тестувань.

На першому етапі при моделюванні інформаційної системи побудувано діаграму IDEF1 (рис. 1, 2) [2]. Функції роботи системи розглянуто з точки зору роботодавця $\mathrm{i}$ претендента.

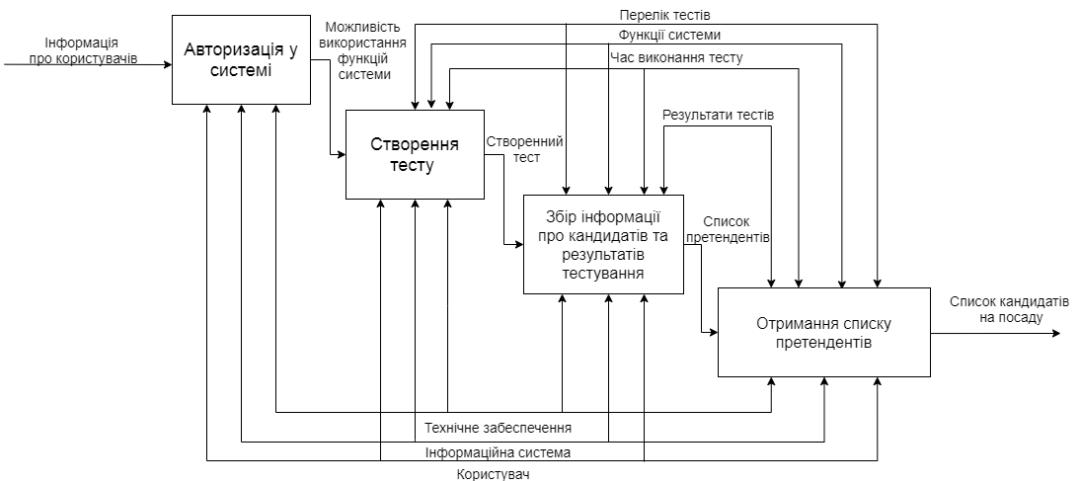

Рисунок 1. Діаграм у нотації IDEF1

3 огляду роботодавця 


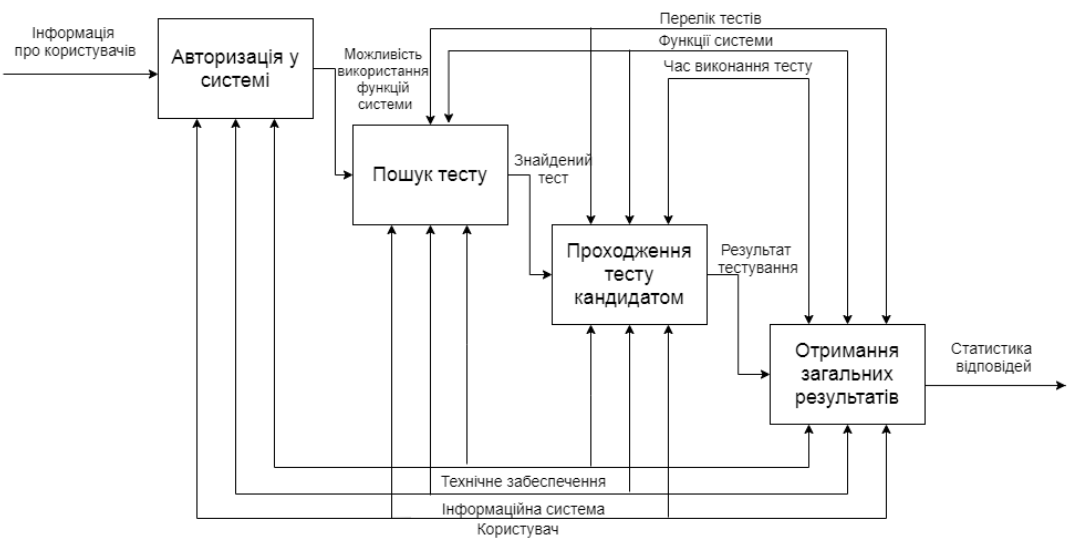

\section{Рисунок 2. Діаграма у нотації IDEF1 з огляду} претендента

ICO3T було реалізовано у вигляді додатків SPA (Single Page Application). Це дозволило розмістити інформаційну систему на одній сторінці, що завантажує одночасно весь код разом із завантаженням самої сторінки.

Головна сторінка ICO3T містить меню навігаційних конопок та опис переваг (рис. 3). 


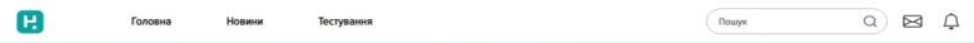

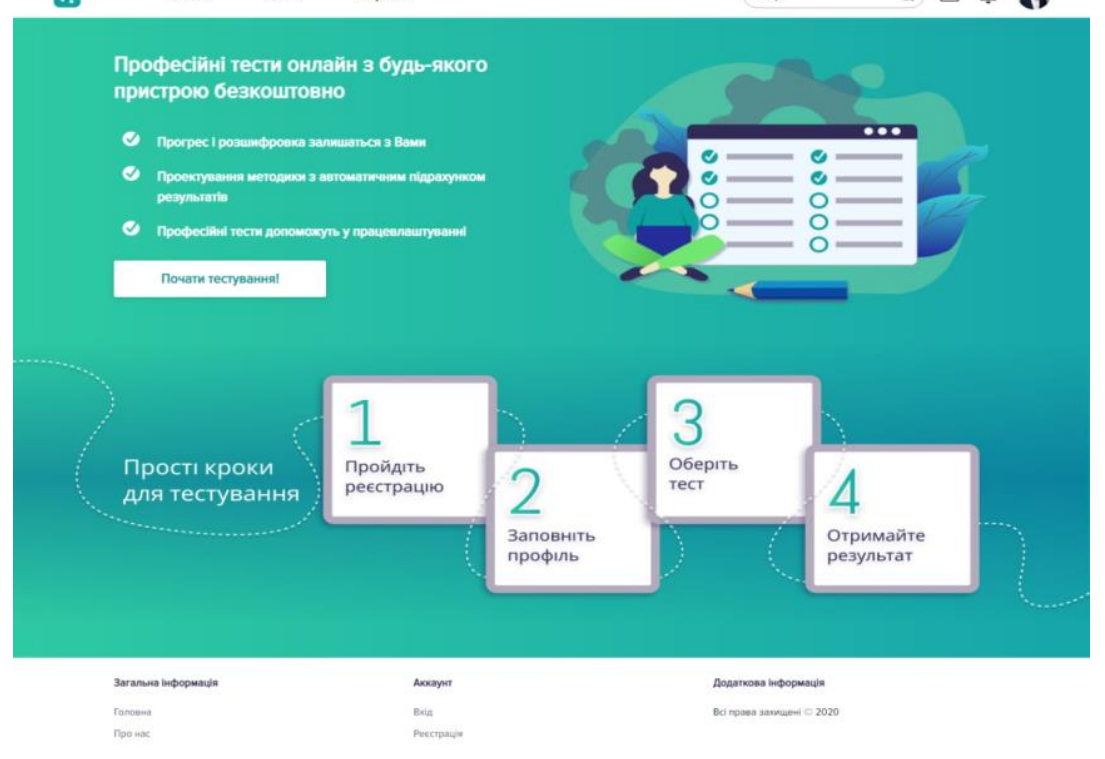

\section{Рисунок 3. Головна сторінка ICO3T}

У меню «Тести» розташований перелік розролених роботодавцями тестів. У претендента $\epsilon$ можливість обрати тест i пройти його Результати тестування будуть відображені в акаунті в меню Мої тести (рис.4).

Користуючись розробленою ICO3T HR спеціалісти отримали можливість проводити аналіз рівня знань претендентів. Тестувальники мають можливість пройти онлайнтестування, переглянути свої результати та отримати зворотню віддповідь від роботодавця в онлайн режимі. 


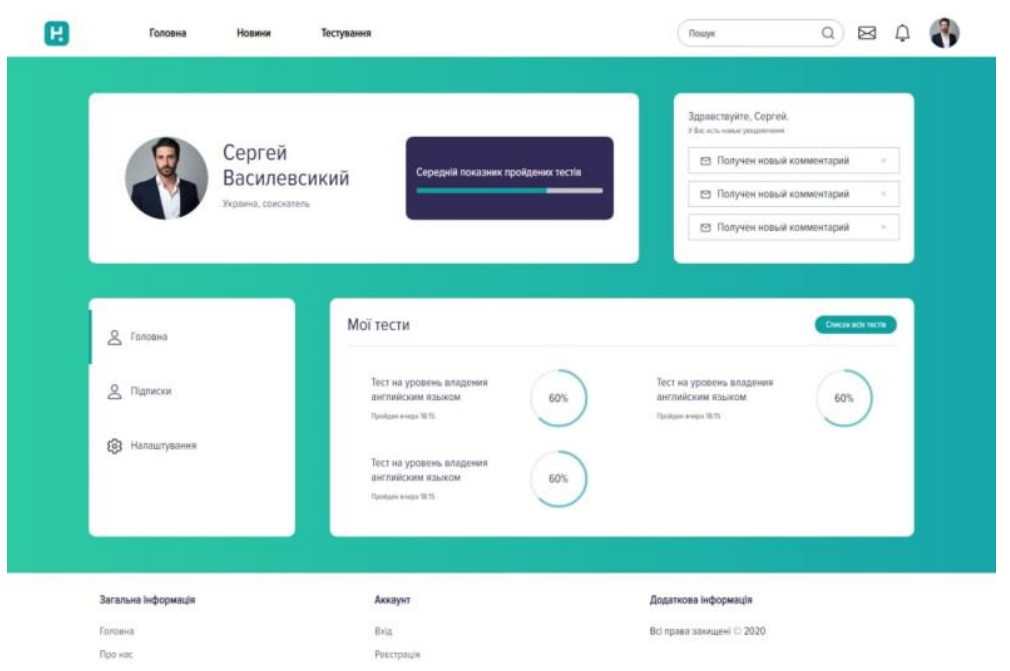

\section{Рисунок 4. Результат тестування на сторінці}

Таким чином, розроблена інформаційна система дозволила полегшити для роботодавців процес відбору претендентів для подальшої співбесіди на вакантні посади. Інформаційна система миттєво надає HR-менеджерам результати, чи має претендент необхідні знання на вакантну посаду, що збільшує швидкість знаходження потрібних співробітників.

\section{Література:}

1. Коронавірус змінив світ. Фахівці назвали п'ять пріоритетів для бізнесу майбутнього [Електронний pecypc] - Режим доступу до pecypcy: https://glavcom.ua/ economics/finances/koronavirus-zminiv-svit-fahivtsi-nazvali-pjat-prioritetiv-dlja-biznesu-majbutnogo-710477.html (дата звернення: 02.07.2021).

2. Christopher M., Mayer R. J. The IDEF Family of Languages. Handbook on Architectures of Information Systems / Ed. P. Bernus, K. Mertins, G. Schmidt. Berlin: Springer Berlin Heidelberg, 2006. P. 215-249. 